\title{
Front Matter: Volume 11099
}

, "Front Matter: Volume 11099," Proc. SPIE 11099, Light in Nature VII, 1109901 (24 September 2019); doi: 10.1117/12.2551011

SPIE Event: SPIE Optical Engineering + Applications, 2019, San Diego, California, SPIE. United States 


\title{
PROCEEDINGS OF SPIE
}

\section{Light in Nature VII}

\author{
Katherine Creath \\ Vasudevan Lakshminarayanan \\ Joseph A. Shaw \\ Editors
}

13 August 2019

San Diego, California, United States

Sponsored and Published by

SPIE 
The papers in this volume were part of the technical conference cited on the cover and title page. Papers were selected and subject to review by the editors and conference program committee. Some conference presentations may not be available for publication. Additional papers and presentation recordings may be available online in the SPIE Digital Library at SPIEDigitalLibrary.org.

The papers reflect the work and thoughts of the authors and are published herein as submitted. The publisher is not responsible for the validity of the information or for any outcomes resulting from reliance thereon.

Please use the following format to cite material from these proceedings:

Author(s), "Title of Paper," in Light in Nature VII, edited by Katherine Creath, Vasudevan Lakshminarayanan, Joseph A. Shaw, Proceedings of SPIE Vol. 11099 (SPIE, Bellingham, WA, 2019) Seven-digit Article CID Number.

ISSN: 0277-786X

ISSN: 1996-756X (electronic)

ISBN: 9781510628915

ISBN: 9781510628922 (electronic)

Published by

SPIE

P.O. Box 10, Bellingham, Washington 98227-0010 USA

Telephone +1 3606763290 (Pacific Time) · Fax +1 3606471445

SPIE.org

Copyright (c) 2019, Society of Photo-Optical Instrumentation Engineers.

Copying of material in this book for internal or personal use, or for the internal or personal use of specific clients, beyond the fair use provisions granted by the U.S. Copyright Law is authorized by SPIE subject to payment of copying fees. The Transactional Reporting Service base fee for this volume is $\$ 21.00$ per article (or portion thereof), which should be paid directly to the Copyright Clearance Center (CCC), 222 Rosewood Drive, Danvers, MA 01923. Payment may also be made electronically through CCC Online at copyright.com. Other copying for republication, resale, advertising or promotion, or any form of systematic or multiple reproduction of any material in this book is prohibited except with permission in writing from the publisher. The CCC fee code is $0277-$ $786 \mathrm{X} / 19 / \$ 21.00$.

Printed in the United States of America by Curran Associates, Inc., under license from SPIE.

Publication of record for individual papers is online in the SPIE Digital Library.

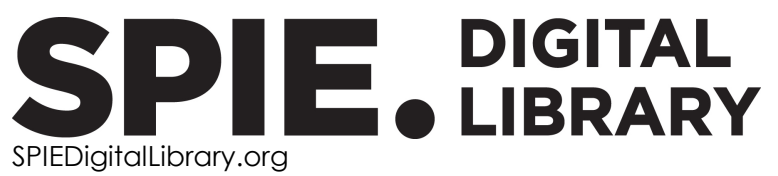

Paper Numbering: Proceedings of SPIE follow an e-First publication model. A unique citation identifier (CID) number is assigned to each article at the time of publication. Utilization of CIDs allows articles to be fully citable as soon as they are published online, and connects the same identifier to all online and print versions of the publication. SPIE uses a seven-digit CID article numbering system structured as follows:

- The first five digits correspond to the SPIE volume number.

- The last two digits indicate publication order within the volume using a Base 36 numbering system employing both numerals and letters. These two-number sets start with $00,01,02,03,04$, 05, 06, 07, 08, 09, OA, OB ... 0Z, followed by 10-1Z, 20-2Z, etc. The CID Number appears on each page of the manuscript. 


\title{
Contents
}

\author{
$\checkmark \quad$ Authors \\ vii Conference Committee
}

\section{LIGHT IN THE PHYSICAL SCIENCES}

$1109902 \quad$ Exploring natural gems and minerals by multiphoton microscopy [1 1099-1]

1109903 Optical vortex emitted from free electrons in nature [1 1099-2]

1109904 Impact of viewing distance on relative depth judgements for stimuli in physical space [1 1099-3]

1109905 Probing the orbital angular momentum spectrum of complex incoherent mixtures [1 1099-4]

LIGHT IN THE NATURAL WORLD

1109906 Observing the mid-latitude aurora [1 1099-5]

1109909 Polarization, reflection, and transmission states of plane electromagnetic propagation through a reciprocal chiral slab [1 1099-8]

\section{LIGHT IN THE BIOLOGICAL SCIENCES}

11099 OA Maxwell, color vision, and the color triangle [1 1099-9]

11099 OD Detection of heavy metals in hydric resources through the optical analysis of exposed flora [11099-13] 
Proc. of SPIE Vol. 11099 1109901-4 Downloaded From: https://www.spiedigitallibrary.org/conference-proceedings-of-spie on 26 Apr 2023
Terms of Use: https://www.spiedigitallibrary.org/terms-of-use 


\section{Authors}

Numbers in the index correspond to the last two digits of the seven-digit citation identifier (CID) article numbering system used in Proceedings of SPIE. The first five digits reflect the volume number. Base 36 numbering is employed for the last two digits and indicates the order of articles within the volume. Numbers start with 00, 01, 02, 03, 04, 05, 06, 07, 08, 09, 0A, 0B...0Z, followed by 10-12, 20-2Z, etc.

Ataai, Rajab Y., 09

Carrión Mogrovejo, J., OD

Chatterjee, Monish R., 09

Cromey, Benjamin, 02

Fritz, Eric, 02

Herrera Valdiviezo, M., OD

Jankovska, Gunita, 04

Katoh, Masahiro, 03

Kieu, Khanh, 02

Knox, Ryan J., 02

Konosonoka, Vita, 04

Krumina, Gunta, 04

Lakshminarayanan, Vasudevan, $0 \mathrm{~A}$

Miyamoto, Yoko, 05

Panke, Karola, 04

Pladere, Tatjana, 04

Salla, Gangi Reddy, 05

Sánchez Juárez, A., OD

Shaw, Joseph A., 06

Villa Achupallas, M., OD 
Proc. of SPIE Vol. 11099 1109901-6 Downloaded From: https://www.spiedigitallibrary.org/conference-proceedings-of-spie on 26 Apr 2023
Terms of Use: https://www.spiedigitallibrary.org/terms-of-use 


\title{
Conference Committee
}

\author{
Conference Chairs \\ Katherine Creath, Optineering (United States) and The University of \\ Arizona (United States) \\ Vasudevan Lakshminarayanan, University of Waterloo (Canada) \\ Joseph A. Shaw, Montana State University (United States) \\ Conference Program Committee \\ Indrani Bhattacharya, University of Calcutta (India) \\ Maria Luisa Calvo Padilla, Universidad Complutense de Madrid \\ (Spain) \\ Akhlesh Lakhtakia, The Pennsylvania State University (United States) \\ Yoko Miyamoto, The University of Electro-Communications (Japan) \\ Lorian Schweikert, Florida International University (United States) \\ Qiwen Zhan, University of Dayton (United States)
}


Proc. of SPIE Vol. 11099 1109901-8 Downloaded From: https://www.spiedigitallibrary.org/conference-proceedings-of-spie on 26 Apr 2023
Terms of Use: https://www.spiedigitallibrary.org/terms-of-use 